\section{PLUMMER-VINSON SYNDROME ASSOCIATED WITH LOWER ESOPHAGEAL RING (SCHATZKI RING) AND HIATAL HERNIA}

\author{
Gabriela Jungblut Schuh ${ }^{1}$, Sandra Jungblut Schuh², \\ Flávia Vieira Lopes ${ }^{3}$, Antônio Carlos Maciel $^{2}$
}

\begin{abstract}
We report a case of Plummer-Vinson syndrome (PVS) and lower esophageal ring with a small sliding hiatal hernia. PVS is a rare entity formed by the combination of dysphagia, cervical esophageal web and iron deficiency anemia. It occurs mainly in middle-aged women ${ }^{1,2,3}$. A lower esophageal ring and a small sliding hiatal hernia were also observed in this case. We documented clinical manifestations of iron deficiency anemia through images and esophageal abnormalities through barium esophagogram.
\end{abstract}

Keywords: Plummer-Vinson syndrome; Paterson-Brown-Kelly syndrome; sliding hiatal hernia; lower esophageal sphincter; iron deficiency anemia

\section{CASE REPORT}

A 39-year-old woman presented with dysphagia, odynophagia and weight loss. She reported that those symptoms started a long time ago, with gradual progression during the previous 6 months. She reported no heavy menstrual bleeding. Physical examination revealed nail deformity compatible with koilonychia (Figure 1a), angular cheilitis (Figure 1b) and atrophy of the tongue papillae (Figure 1c). Her body mass index (BMI) was $19.2 \mathrm{~kg} / \mathrm{m}^{2}$.

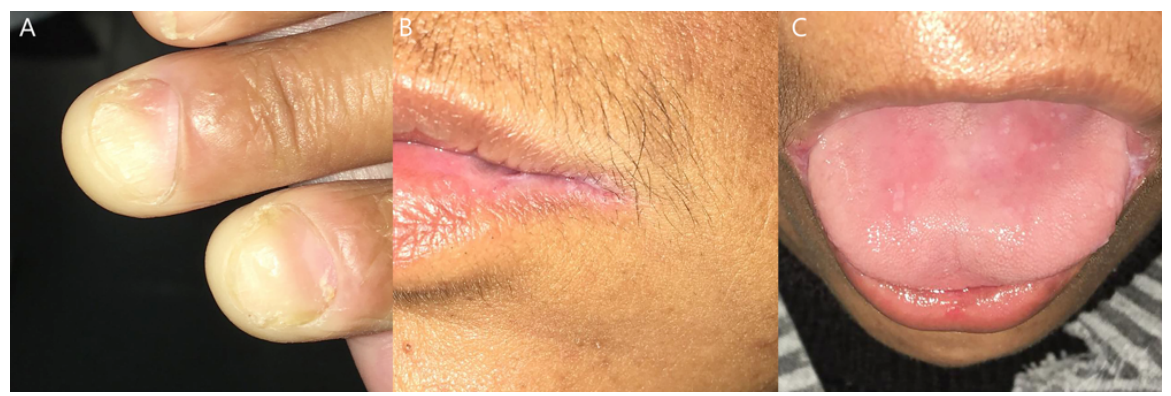

Figure 1: A: Koilonychia; B: Angular cheilitis; C: Atrophy of the tongue papillae.

Laboratory tests were performed, revealing microcytic hypochromic anemia and thrombocytosis. Hemoglobin level was $6.4 \mathrm{~g} / \mathrm{dL}$ (reference range: 11.6-15.6 g/dL), hematocrit was $23.9 \%$ (reference range: $36.0-48.0 \%$ ), mean corpuscular volume was $53 \mathrm{fL}$ (reference range: $80-98 \mathrm{fL}$ ), red blood cell count was $4.52 \mathrm{million} / \mu \mathrm{L}$ (reference range: $4.0-5.4 \mathrm{million} / \mu \mathrm{L}$ ), mean corpuscular hemoglobin was $14 \mathrm{pg}$ (reference range: $28-32 \mathrm{pg}$ ), mean corpuscular hemoglobin concentration was $26.8 \mathrm{~d} / \mathrm{dL}$ (reference range: $32-36 \mathrm{~d} / \mathrm{dL}$ ), red cell distribution width was $21.5 \%$ (up to $15.0 \%$ ) and platelet count was $645.000 / \mu \mathrm{L}$ (reference range: $150.000-440.000 / \mu \mathrm{L}$ ).

Other laboratory test results were as follows: serum iron: $6 \mu \mathrm{g} / \mathrm{dL}$ (reference range: $50-170 \mu \mathrm{g} / \mathrm{dL}$ ); serum ferritin: $4 \mathrm{ng} / \mathrm{mL}$ (reference range: $10-291 \mathrm{ng} / \mathrm{mL}$ ); transferrin saturation: $2 \%$ (reference range: $20-50 \%$ ); total iron-binding capacity:
Clin Biomed Res. 2019;39(4):353-355

1 Faculdade de Medicina, Universidade Federal do Rio Grande do Sul (UFRGS). Porto Alegre, RS, Brasil.

2 Departamento de Radiologia e Diagnóstico por Imagem, Hospital Santa Casa de Misericórdia de Porto Alegre. Porto Alegre, RS, Brasil.

3 Departamento de Medicina Interna, Hospital Santa Casa de Misericórdia de Porto Alegre. Porto Alegre, RS, Brasil.

Corresponding author: Gabriela Jungblut Schuh gschuh@hcpa.edu.br Faculdade de Medicina, Universidade Federal do Rio Grande do Sul (UFRGS) Ramiro Barcelos, 2400. 90035-003, Porto Alegre, RS, Brasil. 
$318 \mu \mathrm{g} / \mathrm{dL}$ (reference range: $250-450 \mu \mathrm{g} / \mathrm{dL}$ ); vitamin B12: $260 \mathrm{pg} / \mathrm{mL}$ (reference range: 193-982 pg/mL); serum folate: $10.6 \mathrm{ng} / \mathrm{mL}$ (reference range: $3.0-17.0 \mathrm{ng} / \mathrm{mL}$ ).

Because of the patient's obstructive symptoms and significant iron deficiency anemia, imaging studies of the upper gastrointestinal tract were performed. Digestive endoscopy was interrupted because of patient intolerance as well as resistance to the passage of the device in the cervical esophagus.
Contrast radiography of hypopharynx, esophagus, stomach and duodenum showed membranes in the anterolateral and posterior walls, apparently forming a complete ring in the cervical esophagus, which determined a significant reduction in its lumen. There was also a lower esophageal ring approximately $5 \mathrm{~mm}$ thick and $5 \mathrm{~mm}$ in diameter and a small sliding hiatal hernia with the gastroesophageal junction, protruding $2.2 \mathrm{~cm}$ above the diaphragmatic hiatus (Figure 2).

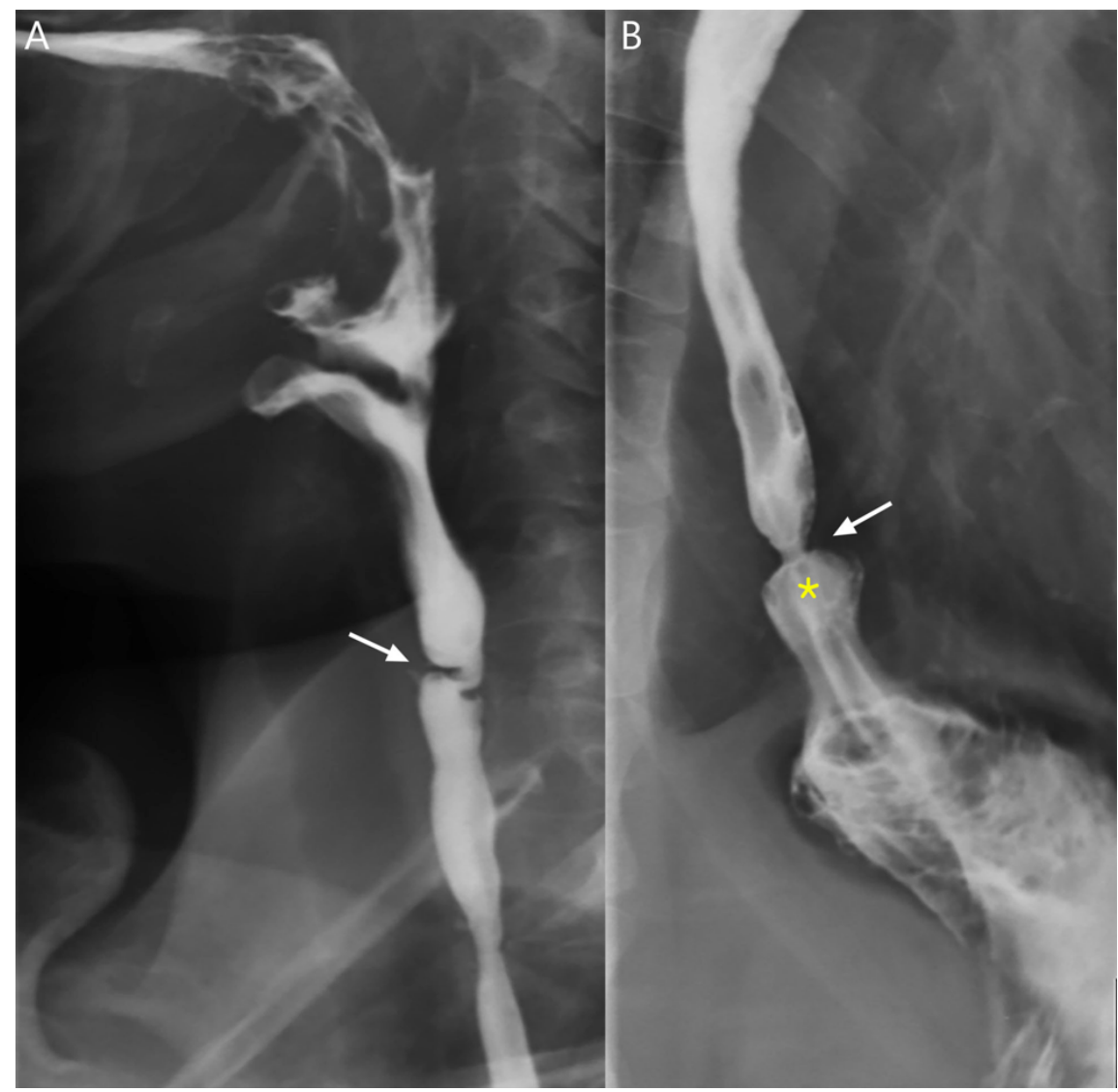

Figure 2: Barium esophagogram. A: Web (arrow) constricting the lumen of the esophagus; B: Prominent inferior esophageal ring (arrow) and small sliding hiatal hernia (asterisks).

In the outpatient clinic, iron supplementation therapy was started and an upper endoscopy with esophageal dilation was ordered for further evaluation and treatment. Additionally, a medical appointment was scheduled for the patient after the procedure. Unfortunately, the patient did not attend the procedure nor the appointment. The follow-up was lost.

\section{DISCUSSION}

Plummer-Vinson syndrome (PVS), also known as Paterson-Brown-Kelly syndrome and sideropenic dysphagia ${ }^{1}$, is a rare entity that occurs mainly in middle-aged women ${ }^{1-3}$. The disorder is characterized by the combination of dysphagia with esophageal web and iron deficiency anemia. An esophageal web is usually located in the proximal esophagus, consisting of a thin ( $1 \mathrm{~mm}$ to $2 \mathrm{~mm}$ ) mucosal fold that typically appears as a diaphragm-like membrane. It is perpendicular to the long axis of the esophagus, constricting its lumen ${ }^{4,6}$. The esophageal web is usually semicircular and almost always arises from the anterolateral wall, but it may form a complete ring ${ }^{1}$. Patients with PVS have increased risk of developing carcinoma of the pharynx or esophagus ${ }^{1,2}$.

Clinical manifestations of iron deficiency anemia are angular cheilitis, glossitis and koilonychia. Glossitis consists of painful tongue with papillae atrophy ${ }^{3,5}$. Koilonychia (spoon nails) is a less common 
finding in physical examination but highly specific in iron-deficient states ${ }^{6}$. The patient presented with microcytic hypochromic anemia, reduced iron, ferritin and transferrin saturation and thrombocytosis. All of those laboratory abnormalities are manifestations of sideropenic anemia.

A Schatzki ring is a mucosal fold at the esophagogastric junction that may or may not be associated with symptoms ${ }^{3,4}$. It is usually symptomatic when the fold is thickened to 4 to $5 \mathrm{~mm}$ and the luminal aperture is narrowed to less than $12 \mathrm{~mm}$. Clinical manifestations include intermittent episodic dysphagia to solids, often associated with substernal pain. The obstructive symptoms may be relieved by drinking liquids or regurgitating the ingested material. Occasionally, an impacted bolus must be removed through endoscopy 4 .

The term lower esophageal ring was proposed in radiology because of a difficulty to distinguish a
Schatzki ring from an annular peptic structure involving the esophagogastric junction ${ }^{1}$. Lower esophageal ring is associated with sliding hiatal hernia ${ }^{1,4}$. Gastric hernia occurs when the esophagogastric transition is above the esophageal hiatus. It affects about $10 \%$ of the population and prevalence increases with age $^{7}$. In individuals in the 6th decade of life, the reported prevalence of these hernias is $50 \%$ to $60 \%{ }^{5,8}$. Paul \& Juhl report that small hiatal hernias are normal findings or changes associated with aging $^{9}$. Radiographic criteria for the diagnosis of sliding hernia are gastroesophageal junction more than $2 \mathrm{~cm}$ above the hiatus ${ }^{1,7}$, three or more gastric folds passing through the hiatus or diaphragmatic hiatus more than $3 \mathrm{~cm}$ in diameter ${ }^{1}$.

\section{Conflicts of Interest}

The authors declare no conflicts of interest.

\section{REFERENCES}

1. Dorland WA. Dorland's illustrated medical dictionary. 28th ed.

Philadelphia: W.B. Saunders, 1999.

2. Sutton D. Tratado de radiologia e diagnóstico por imagem. 6th ed. Rio de Janeiro: Revinter; 2003. Portuguese.

3. Putman CE, Ravin CE. Textbook of diagnostic imaging. 2nd ed. Philadelphia: W.B. Saunders; 1994.
4. Margulis AR, Burhenne H. Practical alimentary tract roentgenology. 5th ed. St. Louis: Mosby; 1994.

5. Kasper DL, Fauci AS, Hauser SL, Longo DL, Jameson JL, Loscalzo J. Medicina interna de Harrison. 19th ed. Porto Alegre: AMGH; 2017.

6. Goldman L, Schafer Al. Goldmancecil medicine. 25th ed. Amsterdam: Elsevier, 2018.
7. Silva CIS, D'ippolito G, Rocha AJ, Caldana RP. Gastrointestinal. Rio de Janeiro: Elsevier; 2011.

8. Brambs HJ. Diagnóstico por imagem gastrintestinal. São Paulo: Artmed, 2009.

9. Juhl JH, Crummy AB, Kuhlman JE. Interpretação Radiológica. 7th ed. São Paulo: Guanabara, 2000.

Received: Oct 6, 2019 Accepted: Dec 11, 2019 